\title{
Pension system of Georgia - reforms and challenges
}

\author{
Jaba Urotadze \\ Jaba Urotadze, PhD, assistant professor \\ Ivane Javakhishvili Tbilisi State University, Georgia
}

\begin{abstract}
.
In 2018, a mandatory funded pension model was introduced in Georgia and today, Georgian pension system has three pillars.

In Georgia, a voluntary funded pension system was established 20 years ago, but received little attention from public and business, one of the reasons of which is lack of stimulating regulations.
\end{abstract}

Pension replacement rate from the first pillar is just under $18 \%$ - much lower than in any of the OECD member states. The fact that the amount of pension does not depend on the length of employment, decreases trust in the system.

Since 2018, the funded pension system became mandatory for employees under age of 40 , for older employees, it is voluntary, but the reform does not apply to today's pensioners and those who will be retiring in few years' time, because they will not have enough time to accumulate sufficient amount for adequate pension levels in retirement.

If the society will not have trust in all three pillars of the pension system, chances of reversing the last year's pension reform will rise, due to several reasons:

a) Replacement rate from the first pillar is low;

b) For the majority of participants of the second pillar, pension payments will start in 20-25 years' time; such a long period of time creates uncertainty in many, about whether the long-term economic growth will be reached, which makes possible achieving an adequate level of retirement income.

Consequently, a significant part of the population may consider, that contributions to the second pillar must be diverted to the first pillar and if it happens, and a pay as you go system remains the only source of pension payments, the pressure on the budget and taxpayers will be very high and it will become much harder to provide necessary financial resources for adequate pension levels.

Keywords: Georgia, pension, pension pillars, pension replacement rate, reform. 


\section{Introduction}

Independent Georgia ${ }^{1}$ inherited the Soviet pension system. According to the report of the World Bank (1993), Pensions were equal to 55\% of last year's salary, or last 5 years' salary whichever was more favorable for pensioner. Pensions were financed through social contributions paid by employer (37\% of salary for private organizations, $26 \%$ for budget organizations) and employee (1\% of salary). Pension age was 60 for men and 55 for women.

Since 1992, because of economic crisis, revenues to finance pensions were diminishing and therefore pensions were not paid regularly (The World Bank, 1993); so it became impossible to have a pension system with a goal to maintain adequate standard of living relative to the income before retirement. Since 1993, the amount of pension did not depend on the wage person had before retirement as it became flat rate and amounted to 50 US cents equivalent per month; there was no automatic indexation, therefore the benefit rate depended on will of the government. In order to ease the burden on budget, pension age increased in 1996 and became 65 for men and 60 for women. In August 1998 pensions rose to 14 GEL (11 USD), the rate did not change till 2004, but lost its purchase power due to inflation. Since 2004, pension benefit rate started to increase gradually, but they are still on the verge of international poverty line set by the World Bank $-1,9 \%$ per day ${ }^{2}$.

Today, pensions are financed through general taxes, from state budget; the goal of the system is to decrease poverty level. Pension is flat rate and amounts to $200 \mathrm{GEL}$, but with one exception, since 2015, pensioners who live in mountainous region will additionally receive $20 \%$ of flat rate pension. Pension replacement rate (the ratio between pension benefits upon retirement and pre-retirement earnings) is 17,8\%, which is much less than in Organization for Economic Co-operation and Development (OECD) and EU countries, as reported by OECD (2017) - 53\% and 58\% respectively.

Voluntary funded pension system was established in 1999, but received little attention from public and business, one of the reasons of which is lack of stimulating regulations (e.g., tax benefits).

In 2018, pension reform was carried out, by introducing mandatory, defined contribution funded pension model; the argument for the reform is that, due to population ageing, it will be much harder to maintain adequate level of pension benefits through existing redistributive, "pay as you go" system. it is expected that the reformed pension system will increase replacement rate and save significant amount of state budget resources in the future, as the amount of pension benefits will not depend solely on state budget. the pension age in mandatory funded pension system is the same as for the state pension - 60 for women and 65 for men. Only disabled persons have a right to withdraw savings before retirement; but on the other hand, there are strong financial incentives to encourage participation in the system: contributions, investment return and pension payments are tax exempt, income tax is paid after making pension contribution. Employee contributions are deducted from the tax base. contributions are paid by employer and employee - $2 \%$ each, plus the state is paying matching contribution, which amounts to $2 \%$ for those employees whose yearly income is below

${ }^{1}$ Georgia declared independence from Soviet Union in April 9, 1991.

${ }^{2}$ For more detailed overview of Georgian pension system see Urotadze (2018). 
$24000 \mathrm{GEL} ; 1 \%$ for those, whose yearly income is from 24000 to 60000 GEL (for those, whose income is above 60000 GEL no matching contributions are paid).

After the mentioned reform, Georgian pension system has three pillars (which is quite common, as efficient pension systems throughout the world are multi pillar): I pillar mandatory state redistributive pension system, where pensions are paid to current pensioners from general taxes; II pillar - mandatory funded pension; III pillar voluntary funded pension.

Population of Georgia is ageing, number of elderly people and their share in total population is projected to increase in the future (figure 1). There will be sharp increase in old age dependency ratio (number of persons aged 65 and older per 100 persons of working age -15 to 65) from 21,5 in 2015 to 41 in 2060 and 50 in 2090 (United Nations, 2019).

Figure 1: Age structure of Georgia's population

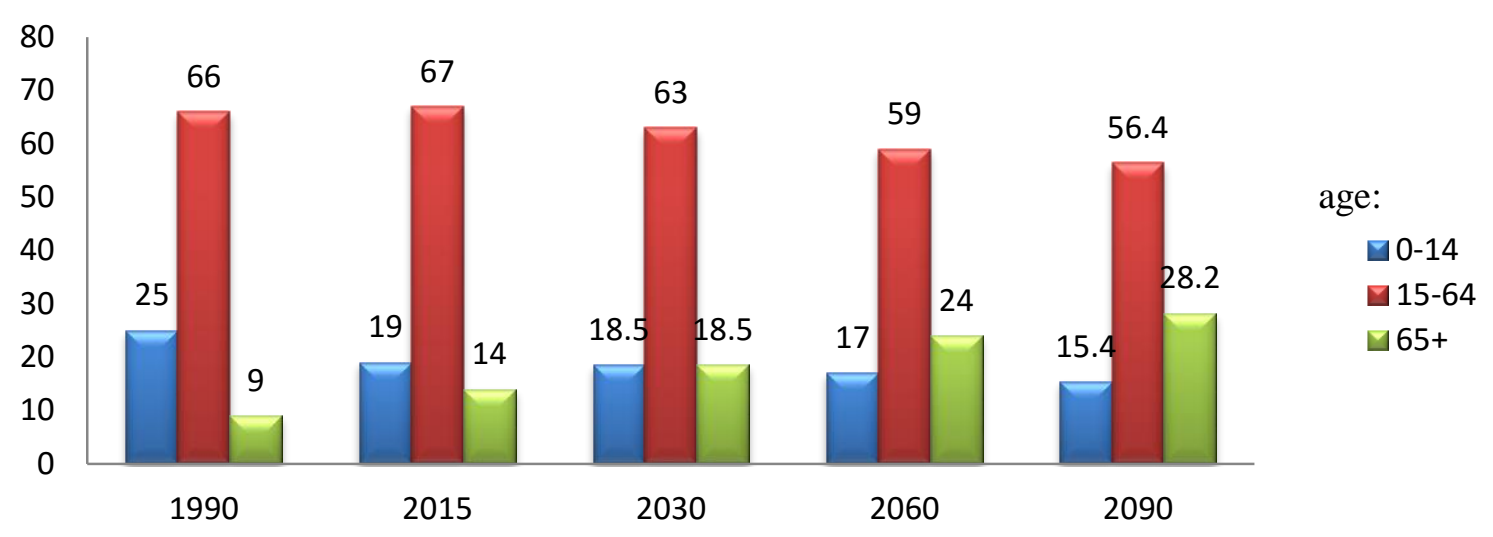

(United Nations, 2019)

GDP per capita in Georgia is one of the lowest in Europe. Old age pension expenditure constitutes 4,2\% of GDP in Georgia; in OECD countries this number reaches 7,5\% on average (OECD, 2019A), The reason of this difference is, that during the last decade Georgia pursues liberal tax policy: social tax in Georgia stood at $20 \%$ when it was abolished in 2008, instead income tax increased from 12 to $20 \%$, overall, tax burden decreased significantly; so today, the tax burden is much lower in Georgia than in OECD countries $^{3}$. As we can see, budget resources in Georgia are much more limited than in the developed countries, therefore it is necessary to work out an efficient design of multi pillar pension system to achieve a considerable increase in pension benefits in the conditions of limited financial resources. As a new mandatory funded pension system was introduced very recently, a littie more time is needed to assess the level of its success, so this article examines ways of reforming of first and third pillars of Georgian pension system.

During the research, the literature was generated and analyzed from the following resources: National Statistics Office of Georgia, public organizations, international organizations. The secondary data about the following issues was collected and analyzed:

\footnotetext{
${ }^{3}$ Georgia's budget expenditures amount to $23 \%$ of GDP (Ministry of Finance of Georgia, n.d.), while in all OECD member countries this figure is significantly higher, e.g., in France and Finland it is - 57\% pursuant to the OECD data (2019B).
} 
- pension policy;

- legal documents;

- reports of international organizations;

- statistical data.

Based on the results of the analysis, the main findings and recommendations were formulated.

\section{Ways of reforming the first pillar}

Pensions in Georgia are not automatically indexed and their amount/growth depend on the will of the government. In the transitional provisions of the law on Funded Pensions (2018) it is stated that: "Within 9 months of the entry into force of this Law, the Ministry of Finance of Georgia shall submit to the Government of Georgia a package of legislative amendments related to the indexation of state pensions, to ensure the maintenance of the wage replacement rate". So the government took responsibility to maintain the pension replacement rate for the first pillar (though the exact date of fulfilling the obligation is not set), but it is hardly enough as the replacement rate is very low and stands at 17,8\%, which is a decrease from $2016(19,1 \%)$, large part of population aged 40 and older are not participating in the funded pension system so they will only depend on the pensions from the state budget, so it is important to increase the replacement rate from first pillar pensions in order to decrease the risk of poverty at old age. It is also important to introduce the indexation as soon as possible so that the pension does not lose purchasing power.

Today's state pension amounts to 200 GEL per month, which is slightly more than 2 USD per day; it is little higher than international poverty line set by the World Bank $1,9 \%$ per day. Without automatic indexation there is a risk that the government priority for a given year may not include raising pensions which might cause increase of poverty among the elderly population. During last 10 years, state pension was not raised in 2010, 2017 and 2018, while inflation rate in those years were 7\%, 6\% and 2,6\% respectively; it decreased pension replacement rates for given years and contributed to increase in extreme poverty rate of pensioners in 2011 to $8.1 \%$ (compared to $7,3 \%$ in 2009 ) and in 2017 to $3,7 \%$ (compared to $1,7 \%$ in 2015$)^{4}$. With the indexation rule the government will be obliged by law to raise pensions in line with wage growth, because if the pension will be indexed pursuant to inflation, than the replacement rate will continue to decline as the price growth rate is slower than the wage growth in Georgia according to the data from National Statistics Office of Georgia (Geostat, 2019A).

By the time when participants of the mandatory funded pension system will reach pension age and will be getting both state and private pensions and the replacement rate from both type of pension provisions (in case of efficient investment policy and stable economic growth) will be higher compared to older generations who were not participating in private pension provisions, it is possible to change indexation rule, by increasing pensions according to increase in the consumer price index rather than wages for pensioners aged 60 to 65 and the money saved can be directed towards older pensioners; it will be less painful for the politicians to implement than the increase of pension age. Old age pensions have significant effect in poverty reduction not only among pensioners, but in whole population: according to UNICEF report (2017) 3,7\%

${ }^{4}$ Poverty rate figures are taken from the UNICEF report (2017) 
of pensioners and 5\% of total population live in extreme poverty (under $\$ 1.25$ per day), but without pensions these numbers rise to $34 \%$ and $16,5 \%$ respectively; so, besides political infeasibility, the raising of pension age will decrease number of pensioners and increase poverty rate, so it is important to reform first pillar and maintain its sustainability without raising pension age at least in the short or medium term perspective.

For few months (September 2012 - April 2013), the amount of state pensions in Georgia differed according to age - those who were older than 67 received about $14 \%$ higher pensions than younger pensioners, in April 2013 pensions again became flat rate as they increased for pensioners younger than 67. In order to save budget resources, it might be beneficial to impose this principle permanently (as another alternative to increasing pension age). Elderly people aged 70 and older will receive 15-20\% higher pensions, but this should not be a one-off increase as it once happened before; this difference should stay permanent, subject to indexation according to average wage growth. This increase will affect 53\% of pension age population (Geostat, 2019B), and their pension replacement rate will increase in at least 2,7 Percentage points $(20,5 \%)-$ this increase will not affect budget expenditures negatively and the government will not have to seek for additional source of income (increase debt, privatization etc.), as the rate of increase in tax revenues far exceeds this amount. It is important that the amount of pension shall differ by age, because the ability to work decreases as health conditions deteriorate for older pensioners, thus increasing the risk of falling into poverty.

Early retirement and the postponement of retirement is quite common in pension systems throughout the world, e.g. in Estonia, "a person is allowed to retire early, i.e. three years before the retirement age... In such case, the amount of pension is decreased by $0.4 \%$ for each month retired early. The early old-age pension is established for life and it will not be recalculated later into old-age pension... in case of the deferred pension, the pension is increased by $0.9 \%$ for each month by which the person defers applying for his or her pension" (AS Pensionikeskus, n.d.). There is no maximum retirement age in Estonia (OECD, 2017). In the United States, maximum retirement age is 70 (normal - 66) and the bonus is $8 \%$ of pension for each deferred year; it is permitted to retire early, in which case the pension is reduced for each month the insured is younger the full retirement age (The United States Social Security Administration, n.d.). In Austria, maximum retirement age differs by gender: 68 for man, 63 for women (normal ret. age is 3 years lower respectively) (OECD, 2017).

In Georgia, due to limited budget resources and population ageing, introduction of early retirement is not desirable. the amount of state pension is already on the verge of international poverty line and reducing pensions per each month/year of early retirement will have negative effect on elderly peoples' social conditions - they will improve for a short-term period, but will worsen afterwards as they will receive reduced pensions for the rest of their lives. also, it will affect predictability of budget expenditures and the possibility to fulfill pension payment duties by the state - it will be difficult to tell how many people will chose to retire early, and as a consequence, what will be the rate of increase of the number of pensioners during the following years.

Existence of late retirement option enables the state to pay higher pension to those who will choose this option, as life expectancy after retirement will be shorter in these cases and payments will continue for shorter period of time. In Georgia, introduction of this 
option will be another way to increase pension replacement rate. The state will pay bonuses to pensioner for retiring later and enabling state to pay higher pensions (reach higher replacement rate) but not increasing overall pension liabilities. The limit of late retirement age should be set in order to have predictable number of pensioners per year and annual pension expenditures. late retirement bonuses exist in most of the in OECD countries and the amount of bonus does not differ by gender (OECD, 2017) despite differences in life expectancy and it is a fair approach which should be applied in Georgia, because if the bonus will depend on gender, than pensions of women will rise at a slower rate (as their life expectancy is longer) and the gender difference in the amount of pension will rise. It will be fair to introduce equal number of deferred years for man and women and as the normal retirement age is different in Georgia for men and women, unlike the United States, maximum retirement age should also be different. Establishment of bonuses for late retirement will encourage elderly people to work longer, thus decreasing risk of falling into poverty.

As a result of introduction of mandatory funded pension system, people who are enrolled in the system will get different amount of pensions depending on investment returns, number of working years and salary they had before retirement, but for the large part of future pensioners this will happen only in 20 years' time or later, when those who now are younger than 40 years of age will start to retire, while in the coming two decades, for vast majority of retirees, pensions will be paid only from the first pillar the amount of which will be the same despite number of working years and salary before retirement, this fact might decrease trust in the system - those who were working and paying taxes for many years might consider that this as an unfair provision and want to have the same advantage as those enrolled in the mandatory pension system in terms of higher pensions depending on contributions/taxes paid and length of employment, but for current pensioners as well as for those who are close to retirement age (they will not have enough time to accumulate financial resources for adequate pensions from the second pillar) this can happen only by increasing pensions from the first pillar; but the budget resources to finance such increases in pension are very limited, so it is essential to find aditional source to fund this increase. In Georgia, since independence there was a short period of time from 2007 to 2012 when the amount of pensions depended on length of employment, but the amount added to the basic pension was symbolic and was making a little difference ${ }^{5}$.

First pillar pensions are usually financed through social contributions paid by employer, (often by employee as well), but in Georgia under the government's liberal economic policies at the time, social tax was abolished in 2008; ten years later, social contributions are reinstated but only to finance mandatory second pillar, while for current pensioners and those who are close to retirement age, pensions are still paid from the general taxes allocated in the budget, in order for the pension system to be equally fair to future and todays pensioners, social contributions to finance redistributive "pay as you go" pension should be introduced. But this time, differences should not be symbolic as it was several years before. In the following paragraphs, specific recommendations are given for implementing contribution based redistributive

\footnotetext{
${ }^{5}$ Minimal supplement was 2 GEL for up to 5 working years, while maximum supplement was $10 \mathrm{GEL}$ for more than 25 working years. Further increases in pension abolished the differences again.
} 
"pay as you go" pension model, which might be functioning as a supplement to existing flat rate social pensions:

a) The amount of supplement should depend on length of employment, not on salary/contributions paid before retirement: in Georgia, income inequality (measured by Gini coefficient - the most frequently used measurement of inequality) is the highest in Europe (The World Bank, 2019); and if the amount of pension will depend on income before retirement, then the inequality will increase. In Georgia there is a sharp difference in wages by regions, spheres of employment and gender (Geostat, 2019D) the average monthly wage in the poorest region is $40 \%$ that of capital Tbilisi; in speres of agriculture and education wages are approximately three times lower than in financial and insurance sector; while women receive two-thirds of men's wage.

Georgian mandatory funded pension system is based on defined contribution principle where the benefit depends on the contributions paid and the investment return; thus, the amount of pension from the second pillar strongly depends on income before retirement, and if the same principle will be used in both pillars, it will widen the income inequality among pensioners.

b) It is desirable that pension age is equal for men and women for supplementary state pension based on length of employment and should stand at 65 years. Taking into consideration growing number of pensioners due to population ageing, this will save significant financial resources (women aged 60-65 constitute almost $20 \%$ of all pensioners) to pay higher pensions to older retirees, while right to get flat rate social pension for women from the age of 60 will be left unchanged. In about 20 years' time the pension age for length of employment based pension should be increased according to life expectancy, because when participants of second pillar (whose enrollment was mandatory) will start to retire, they will have higher pension replacement rates (in case of stable long term economic growth and efficient management of the system), as they will get pensions from both pillars instead of only from the state pension system, and therefore this increase of pension age will supposedly have much smaller resistance from society compared to the introduction of this principle before the mentioned date.

c) In order to acquire the right to full supplementary pension, maximum number of working years has to be set. For example, in Romania the full contribution period for women is 30 years and 9 months and will increase gradually to 35 years by January 2030, while the full contribution period for men is 35 years (European Commission's DG for Employment, Social Affairs \& Inclusion, 2019).

Due to high rates of unemployment and informal employment (Geostat, 2019C), maximum number of working years should be lower than in Romania, because otherwise it will be difficult for many pensioners to acquire the right to full supplementary pension. Therefore it is more appropriate to set the mentioned period at 25 years as it was from 2007 to 2012 (see page 6); if the number of years is fewer, the supplementary pension will decrease accordingly.

Employment rate among women is lower compared to men - 49 and 63,4 percent respectively (Geostat, 2019C) and that's why the maximum number of working years should be different (e.g. 5 years' difference: 20 years for women; 25 years for men) in order to reduce gender difference in pension benefits. 
d) In order to maintain fiscal sustainability of the supplementary pensions, benefit growth rate should depend on social contributions collected, rather than consumer price index or average wage growth, thus making it a defined contribution scheme, which will be free from pressure coming from population ageing.

e) Decision should be taken about the level of contribution and who should pay them. Tax increase can cause discontent among population, so the rate of increase should not be too high, but significant enough to make a difference in the amount of pension. Burden of contribution increase should not be born only by employer or employee, social responsibility should be shared by both parties of employment relationship; the level of discontent might be mitigated by not placing too much tax burden on either side. Introduction of $1 \%$ of social contribution will cause additional revenue of $1 \%$ of wages fund, which in 2018 was roughly 160 million GEL ${ }^{6}$. In order to avoid excessive financial burden on the population, It is desirable to divert part of the income tax (at least $1 \%$ - approximately 160 million GEL) to the supplementary pension scheme; this will not reduce income tax revenues necessary to finance other programs/spheres ${ }^{7}$. If social contribution rate on employer and employee is at least $1,25 \%$ apiece, total contribution rate shall be $3,5 \%$, which in 2018 would have been roughly 560 million GEL; it would enable an increase in maximum pension benefits by nearly 75 GEL per month $^{8}$ - a $38 \%$ increase.

\section{Ways of reforming the third pillar}

In 1999, voluntary funded pension system (VFPS) was established, but it is poorly developed and regulated (slightly over $1 \%$ of workforce is insured). There are no tax benefits in the system; also, there are no limitations by law on early withdrawal of pension assets, thus there are no long-term funds, which hinders investments in long term instruments; practically, asset management is not conducted - pension assets are almost entirely invested in bank deposits and investment return rate coincides with the interest rate on short-term bank deposits.

In order to raise interest for asset managers in VFPS it is necessary to have long-term funds, so there is a need to incentivise long term savings and disencourage early withdrawal of pension assets, but those limitations shoul be less strict compared to mandatory funded pension system (MFPS), therefore it is desirable to introduce financial incentives, which can be tax incentives and non-tax incentives - matching contributions and fixed subsidies ${ }^{9}$. financial incentives should be the same as in MFPS (see page 2), but as the contribution rates in VFPS are not set, the maximum treshold might be placed for the right to apply these incentives as the amount of tax revenues should be under control in order to maintain fiscal stability: financial incentive may not be given for contribution higher than $2 \%$.

\footnotetext{
${ }^{6}$ In 2018, income tax revenue was 3250 million GEL (Geostat, 2019E), hence wages fund should have been approximately 16 billion GEL (as the income tax is one fifth of wages fund).

${ }^{7}$ During the period of 5 years (2014-2018), income tax revenues increased by 328 million GEL on average.

${ }^{8}$ This number is received by dividing 560 million GEL by the number of pensioners taken from

Geostat (2019F) - 745 thousand.

${ }^{9}$ Designs of financial incentives are given in OECD report (2018).
} 
Retirement age has to be set, which should be lower than in state pension system, For example in Estonia ${ }^{10}$, the normal retirement age is 63 (will be increased to 65 in the future) in the first pillar "pay as you go" system and in the second pillar MFPS, while in the third pillar it is 55 (tax incentives apply to the payments only after the person has become 55 years old). In the future, it might be benefitial to increased according to life expectancy, because as reported by the United Nations (2019), life expectancy in Georgia is expected to rise considerably in the following decades and consequently the pension savings will have to be paid for a longer period (if the pension age in third pillar remains unchanged), which will decrease monthly pensions.

In setting the limits for early withdrawal, it will not be advantageous to follow Estonia's example where participants can receive payments from the VFPS whenever they wish (but if they decide to withdraw savings before normal retirement age, they will not receive tax benefits), because in Estonia, even without the third pillar, there is much higher pension replacement rate than in Georgia, that's why it is more important for Georgia to try to keep persons in the third pillar up to the retirement age, but impose limited number of exceptions for withdrawing savings early. Example of New Zealand private funded pension saving scheme - KiwiSaver (Inland Revenue Department of New Zealand, n.d.) might be more useful: You may be able to withdraw your savings (provided you leave a minimum balance of $\$ 1,000$ in your account) to put towards purchasing your first home, provided that you are a KiwiSaver member for three or more years; In case of significant financial hardship (exact criterias has to be determined by the legislation), which includes following: unable to meet minimum living expenses; unable to meet mortgage repayments on the home you live in, resulting in your mortgage provider enforcing the mortgage on your property; modifying your home to meet special needs because of you or a dependent family member having a disability; paying for medical treatment if you or a dependent family member: becomes ill, has an injury, or requires palliative care; incurring funeral costs if a dependent family member dies; if you have an illness, injury or disability that either permanently affects your ability to work or poses a risk of death.

To attract more participants in the third pillar, they should be given the right to: freely determine the contribution rate; change the size of the contribution at any time and suspend contributions temporarily. Same regulations are in Estonia's third pillar (while participant of second pillar mandatory funded pension don't have a right to receive payments before retirement). This will likely be an advantage compared to MFPS, where the amount is fixed at $2 \%$ and employee who is ready to contribute less than that should be free to do so in the third pillar - it may increase willingness to participate in VFPS for those who refused to participate in MFPS.

Unlike Estonia's private funded pension system, where only defined contribution plans are allowed, in Georgia's third pillar it is permissible to establish both Defined contribution (DC) and Defined benefit (DB) pension scheme ${ }^{11}$. As there is very small participation rate in VFPS in Georgia, It is probably preferable to maintain the variety of choise in pension schemes to increase the interest. But in both Georgia and Estonia, there are no minimum investment return guarantees for the DC schemes, thus the

\footnotetext{
${ }^{10}$ Information about the Estonian Pension System can be found on the following web site: https://www.pensionikeskus.ee/en/ which is created by Estonian Central Securities Depository.

${ }^{11}$ In DB scheme, the pension provider guarantees that the pension benefit based on a prescribed formula will be paid no matter what the investment return will be.
} 
investment risk is born by an employee. In Estonia it is not causing lack of mistrust in the system, but in Georgia it is an issue, as there is a negative experience in relation to savings, when in early 90 -ies the devaluation of savings took place due to economic crisis and the state still does not have enough financial resources to compensate the losses; it causes mistrust in long-term savings among significant part of the population, which might hamper the substantial increase in voluntary pension savings. It might be benefitial to impose at least minimal guarantees to raise trust in the system and prevent considerable devaluation of savings in case of unsuccessful investment. Level of minimum investment return guarantees vary across the countries: in Germany, voluntary pension plans must guarantee a nominal rate of return of 0 per cent on the accumulated savings at retirement, in Belgium the guaranteed interest rate is set at $1.75 \%$ anually (OECD, 2017). imposing these kind of guarantees can be very costly for the participants, as it raises administrative costs and decreases motivation of asset managers to invest in risky assets, thus lowering chances of high investment returns.

In order to avoid mentioned negative effects from determining guarantees, the state may not establish minimum investment return guarantees unconditionally, rather it can oblige private pension providers to offer, among others, a pension product with minimum investment guarantee, so that a participant will chose himself/herself between riskier investment portfolio with no investment guarantee or the guaranteed pension product with potentally lower but relatively safer investment policy.

Large part of the population don't have enough financial literacy to make investment decisions, so in order to raise trust and confidence in the system, it might be necessary to assign undecided employee (the one who is reluctant to make his/her own decision on the type of investment portfolio) to DC scheme with a minimum investment guarantee by default, at least when there will be few years before retirement; the life cycle approach in determining default options is used in Georgia's MFPS ${ }^{12}$, but without minimum investment guarantee.

\section{Conclusion}

Today's state pension benefits are hardly enough to avoid extreme poverty among elderly, while population ageing will put additional strain on already limited budget resouces. Voluntary funded pension was established in 1999, but the number of participants are very small, one of the reasons of which is lack of stimulating regulations. Mandatory funded pension was introduced very recently and a littie more time is needed to assess the level of its success; nevertheless, vast majority of workers older than 40 are not participating in the private pension schemes, which means that they will get pensions only from the first pillar. Therefore it is necessary to work out an efficient design of multi pillar pension system to achieve a considerable increase in pension benefits in the conditions of limited financial resources. In the research, following recommendations to further enhance efficiency of Georgian pension system are presented:

\footnotetext{
${ }^{12}$ According to the law on Funded Pensions, Pension assets shall be invested in an investment portfolio with three different types of risk and expected profitability. A participant shall have the right to choose investment portfolio, but until a participant exercises this right, the pension assets shall be invested in a high, average or low risk portfolio depending on the age of a participant.
} 
- Pension replacement rate is very low and stands at $17,8 \%$, it has even declined during last several years, therefore it is important to introduce the automatic indexation according to the average wage growth as soon as possible.

- Elderly people aged 70 and older should receive 15-20\% higher state social pensions. It is important that the amount of state pension shall differ by age, because the ability to work decreases as health conditions deteriorate for older pensioners, thus increasing the risk of falling into poverty.

- Introduce bonuses to pensioner for retiring later. It enables state to pay higher pensions but not increasing overall pension liabilities.

- Impose social contributions (paid by both, employer and employee) to finance "pay as you go" pension, the amount of which depends on length of employment.

- In order to raise interest for both - employees and asset managers it is desirable to introduce financial incentives for the participation in the third pillar and set a retirement age which is lower than in state pension system, give wide opportunities for early withdrawal and a right to freely determine the amount of contribution.

- Impose at least minimal guarantees to raise trust in the system and prevent considerable devaluation of savings in case of unsuccessful investment. Private pension providers can be obliged to offer, among others, a pension product with minimum investment guarantee.

\section{References}

1. AS Pensionikeskus. (n.d.). Estonian pension system. Retrieved August 19, 2019, from Pensionikeskus: https://www.pensionikeskus.ee/en/

2. European Commission's DG for Employment, Social Affairs \& Inclusion. (2019). Romania - Old-age pensions. Retrieved from European Commission - Employment, Social Affairs \& Inclusion: https://ec.europa.eu/social/main.jsp?catld=1126\&langld=en\&intPageld=4754

3. Geostat. (2019A). Retrieved from National Statistics Office of Georgia (Geostat): https://www.geostat.ge/en

4. Geostat. (2019B). Population. Retrieved from Geostat: https://www.geostat.ge/en/modules/categories/41/population

5. Geostat. (2019C). Employment and Unemployment. Retrieved from Geostat: https://www.geostat.ge/en/modules/categories/38/employment-and-unemployment

6. Geostat. (2019D). Wages. Retrieved from Geostat: https://www.geostat.ge/en/modules/categories/39/wages

7. Geostat. (2019E). Government Finance Statistics. Retrieved from Geostat: https://www.geostat.ge/en/modules/categories/91/government-finance-statistics 
8. Geostat. (2019F). Social Protection. Retrieved from Geostat:

https://www.geostat.ge/en/modules/categories/55/social-protection

9. Inland Revenue Department of New Zealand. (n.d.). KiwiSaver benefits. Retrieved August 19, 2019, from KiwiSaver: https://www.kiwisaver.govt.nz/new/benefits/

10. Law on Funded Pensions. (2018). Georgia. Retrieved from https://matsne.gov.ge/en/document/view/4280127?publication=0

11. Ministry of Finance of Georgia. (n.d.). Macroeconomic indicators. Retrieved from Ministry of Finance of Georgia: https://www.mof.ge/en/4541

12. OECD. (2017). Pensions at a Glance 2017: OECD and G20 Indicators. Paris: OECD Publishing. doi:https://doi.org/10.1787/pension_glance-2017-en

13. OECD. (2018). OECD Pensions Outlook 2018. Paris: OECD Publishing, Paris. doi:https://doi.org/10.1787/pens_outlook-2018-en

14. OECD. (2019A). Pension spending (indicator). doi:10.1787/a041f4ef-en

15. OECD. (2019B). General government spending (indicator). doi:10.1787/a31cbf4d-en

16. The United States Social Security Administration. (n.d.). United States of America. Retrieved August 19, 2019, from Social Security Programs Throughout the World: The Americas, 2015: https://www.ssa.gov/policy/docs/progdesc/ssptw/20142015/americas/united-states.html

17. The World Bank. (1993). Georgia, a Blueprint for Reforms. Washington D.C.: The World Bank.

18. The World Bank. (2019). GINI index (World Bank estimate). Retrieved from World Bank Open Data:

https://data.worldbank.org/indicator/SI.POV.GINI?most_recent_value_desc=false\&view =map

19. UNICEF. (2018). The well-being of children and their families in Georgia. Tbilisi: UNICEF. Retrieved from https://www.unicef.org/georgia/media/1266/file/WMS\%202017\%20ENG.pdf

20. United Nations. (2019). World Population Prospects 2019. Retrieved from United Nations: https://population.un.org/wpp/DataQuery/

21. Urotadze, J. (2018). Pension Policy of Georgia and International Experience. Tbilisi: Publishing of Ivane Javakhishvili Tbilisi State University. 